\title{
Polyunsaturated Fatty Acids, Riboflavin and Vitamin C: Effects of Different Storage Conditions of Human Milk
}

\section{Milana Abramovich ${ }^{1}$, James K Friel ${ }^{1,2}$ and Zakir Hossain ${ }^{1 *}$}

${ }^{1}$ Human Nutritional Sciences, University of Manitoba, Winnipeg, MB, Canada

${ }^{2}$ Pediatrics, University of Manitoba, Winnipeg, MB, Canada

\begin{abstract}
This study addresses a matter of importance for: healthy infants; sick infants in the Neonatal Intensive Care Units; infants fed expressed human milk and infants who receive milk from Human Milk Banks. Current storage parameters for freezing of mother's milk are not well established and are often contradictory. Pooled fresh human milk was stored raw, in nitrogen gas and following Holder pasteurization for 6 days at $4^{\circ} \mathrm{C}$ and for 6 months at $-20^{\circ} \mathrm{C}$ and at $-80^{\circ} \mathrm{C}$. Contents of linoleic (LA), $\alpha$-linolenic (ALA), arachidonic (ARA) and docosahexaenoic (DHA) acids, riboflavin and total vitamin C were analyzed under these conditions and during these storage times as they are sensitive to oxidation. The results of this study confirm the general appropriateness of freezing human milk at either $-20^{\circ} \mathrm{C}$ or at $-80^{\circ} \mathrm{C}$, for preservation of two vitamins and four fatty acids. These storage recommendations are applicable also for the storage of human milk which underwent Holder pasteurization. Both the exclusion of oxygen and freezing at $-80^{\circ} \mathrm{C}$ may be redundant for nutrient preservation and in some cases even detrimental. Recommendations for human milk storage while based on bacteriological safety appear to be appropriate for preservation of vitamins $C$ and riboflavin and LA, ALA, DHA and ARA. As vitamin C is highly susceptible to oxidation, its addition to human milk or direct supplementation of the infant is recommended, if the milk had been frozen for longer than 2 weeks or had been pasteurized. We recommend supplementation of the infant with vitamin $\mathrm{C}$ at the Adequate Intake (Al) level in these cases.
\end{abstract}

Keywords: Human milk; storage; Fatty acids; Vitamin C; Riboflavin; Holder pasteurization

Abbreviations: LA: Linoleic Acid (18:2n-6); ALA: $\alpha$-linolenic Acid (18:3n-3); DHA: Docosahexaenoic Acid (22:6n-3); ARA: Arachidonic Acid (20:4n-6)

\section{Introduction}

Human milk provides numerous advantages for infants, mothers, families and society [1]. Human milk is sufficient to support optimal growth and development of the infant for approximately the first 6 months of life. Therefore, many health organizations recommend exclusive breastfeeding for this period, defined as the consumption of human milk alone, with the exception of vitamins, minerals and medications [2,3]. The World Health Organization (WHO) recommends continued partial breastfeeding into the second year [3]. When breastfeeding is chosen, some babies may be fed mechanically or hand expressed milk from a bottle, rather than directly from the breast. Mothers express their milk when they have sore nipples, postpartum breast engorgement, in order to increase milk supply, to leave the milk if they are away from their baby and also in situations of adoption or surrogacy [4-10]. Expressed breast milk, often supplemented with nutrients, is used in hospitals for the feeding of premature, small for gestational age and normal term infants who cannot suckle [11]. Breast milk can be donated to human milk banks, which provide pasteurized donor human milk for infants with medical conditions, for adopted infants and for those who are not able to receive their own mother's milk [12]. Heat treated breast milk is recommended for the feeding of infants of HIV-positive mothers in developing countries in order to prevent transmission of the virus through milk [13]. The American Academy of Paediatrics has stated that data on prolonged storage of human milk needs updating [14].

The purpose of human milk pasteurization is to destroy pathogenic microorganisms [15]. Commonly used conditions are $62.5^{\circ} \mathrm{C}$ for 30 minutes ("Holder pasteurization"). Holder pasteurization has been shown to destroy the pathogens in milk, does not affect key nutritional factors, but may have an adverse effect on some of the milk nutritional, functional, immunologic and anti-infective components. Holder pasteurization achieves a sufficient compromise between microbiological safety and biological and nutritional integrity of human milk [16].

Immediately after expression, human milk becomes susceptible to food degradation and its quality may decrease during storage [17] Several methods are used to extend the shelf life of food, including reducing storage temperature and restricting oxygen availability. Lowtemperature storage slows down microbial growth and delays changes in the physiochemical character of milk [15]. Reducing the availability of oxygen using vacuum packaging or nitrogen gas flushing slows down oxidative reactions and reduces microbial growth [18]. Freezing at $-70^{\circ} \mathrm{C}$ or $-80^{\circ} \mathrm{C}$ is considered the gold standard for conservation of human milk for extended periods of time [16] and is a common temperature for storage of other human tissues [19].

Many protocols have been published in an attempt to establish conditions for storage of human milk. Depending on the study, recommended refrigeration storage $\left(4^{\circ} \mathrm{C}\right)$ length varies from 2 days to 8 days [20-22]; frozen storage at $-15^{\circ} \mathrm{C}$ from 2 weeks [22-24] to 1 month [25]; storage at $-18^{\circ} \mathrm{C}$ from 3 months [20] to 12 months [21]; storage at $-20^{\circ} \mathrm{C}$ to 12 months $[21,22,24,25]$. Pasteurized human milk has been recommended to be stored at a temperature $-20^{\circ} \mathrm{C}$, with no established length of time [16]. These guidelines pose 2 problems: firstly, the variation in recommendations makes it unclear which guidelines should be followed. Secondly, they are aimed primarily at avoiding

${ }^{*}$ Corresponding author: Zakir Hossain, Human Nutritional Sciences, University of Manitoba, Canada, E-mail: zakirh1000@yahoo.com

Received January 25, 2013; Accepted January 27, 2013; Published March 22 2013

Citation: Abramovich M, Friel JK, Hossain Z (2013) Polyunsaturated Fatty Acids Riboflavin and Vitamin C: Effect of Different Storage Conditions of Human Milk. Vitam Miner 2: 110.

Copyright: (C) 2013 Abramovich M, et al. This is an open-access article distributed under the terms of the Creative Commons Attribution License, which permits unrestricted use, distribution, and reproduction in any medium, provided the original author and source are credited. 
bacterial growth, while not considering loss of nutritional properties during storage and handling [26,27].

Human milk provides the normative standard for infant nutrition. Nevertheless, many micronutrients vary in human milk depending on maternal diet and body stores [28]. The essential fatty acids including the n-6 linoleic acid (18:2n-6, LA) series and n-3 a-linolenic acid (18:3n-3, ALA) series, are required in the diet to avoid fatty-acid deficiency in both mother and infant [29]. LA and ALA are the essential long-chain polyunsaturated fatty acids (LCPUFA), which are found in cell membrane phospholipids, plasma lipids, storage lipids and in intracellular cholesterol esters [30,31]. Docosahexaenoic acid (DHA, 22:6n-3) and arachidonic acid (ARA, 20:4n-6), the metabolites of ALA and LA, respectively, are the major LC-PUFA components in membranes phospholipids of the brain and retina [30,32]. Preterm infants require DHA and ARA for rapid brain and body growth [30]. The most potent of the n-3 fatty acids is DHA, which has a beneficial anti-inflammatory activity. Another important biological effect of DHA pertains to brain development and cognition [33]. Two hundred milligrams of DHA as a supplement, for the first 4 months of breastfeeding, results in higher infant Bayley Psychomotor Development Scores at 30 months of age [34] and better performance on tests of sustained attention. This suggests that DHA intake during early infancy confers long-term benefits on specific aspects of neurodevelopment [33]. Vitamin C is essential for infant growth and development [35,36]. Its functions are based primarily on its properties as a reversible biological antioxidant [37]. The term vitamin $\mathrm{C}$ is the generic descriptor for all compounds which have the qualitative biological activity of ascorbic acid (AA). The principal natural compound, L-ascorbic acid, is oxidized to dehydroascorbic acid (DHAA) in the body. This reaction is reversible; therefore DHAA exhibits full biological activity. Riboflavin (vitamin $\mathrm{B}_{2}$ ) is a precursor of the flavin coenzymes, flavin adenine dinucleotide (FAD) and flavin mononucleotide (FMN), which participate in oxidation-reduction reactions in many metabolic pathways [37]. Riboflavin is central to energy production. Its other major functions include drug and steroid metabolism and lipid metabolism [38]. Previous studies have been conducted to follow the changes in the content of LA, ALA, ARA, DHA, vitamin $\mathrm{C}$ and riboflavin during storage of human milk at $-20^{\circ} \mathrm{C}$ and $-80^{\circ} \mathrm{C}[27,39-41]$ and following Holder pasteurization [16,42-44]. However, the reasons we selected these 6 nutrients is because from the literature the two water soluble vitamins are very sensitive to oxidation. Therefore we wished to see if we could find the optimum method to of milk storage to preserve these vitamins. Fatty acids were chosen because they are so important to growth and development and liable to oxidation. Oxidized lipids may make the milk undesirable to the infant! We could have chosen many more nutrients but these ones appear to be the most sensitive and representative of milk quality. However, to the best of our knowledge, no studies have assessed the effects of oxygen restriction on the nutrient integrity of human milk after storage at various temperatures, and no studies have analyzed the nutrient content of pasteurized human milk after storage at various temperatures. Our study reports the effects of different storage parameters on the nutrient integrity of mother's milk.

\section{Materials and Methods}

We stored human milk for 6 days at $4^{\circ} \mathrm{C}$ and for 6 months at both $-20^{\circ} \mathrm{C}$ and $-80^{\circ} \mathrm{C}$. Milk was stored raw, in nitrogen gas (to limit oxygen availability) and following Holder pasteurization. Contents of LA, ALA, DHA, ARA, riboflavin and total vitamin $\mathrm{C}$ were analyzed during storage under the differing experimental conditions.

\section{Sample collection and study design}

Five mothers (age range 25-35, healthy) of full-term infants donated their mature breast milk (lactation established for at least 1 month) for a total volume of $300 \mathrm{ml}$ collected by breast pump or hand expression. Milk was delivered to the laboratory on ice. Subsequently, it was heated to $38^{\circ} \mathrm{C}$ and to achieve sufficient volume, was pooled with $400 \mathrm{ml}$ of milk from a single donor of mature milk (age unknown). This pooled milk was apportioned into opaque, hard, polypropylene tubes with tight-fitting lids [45]. Nitrogen gas flushing was applied for $3 \mathrm{sec}$. Holder pasteurization was carried out by holding tubes with human milk in a shaking water bath at $62.5^{\circ} \mathrm{C}$ for $30 \mathrm{~min}$ with subsequent rapid cooling under tap water at $8^{\circ} \mathrm{C}[16,46,47]$. Control, nitrogen flushed and pasteurized samples were placed for refrigerated storage $\left(\right.$ at $\left.4^{\circ} \mathrm{C}\right)$ or for frozen storage (at $-20^{\circ} \mathrm{C}$ or $-80^{\circ} \mathrm{C}$ ). All treatments were completed within 2 hours of delivery of the milk to our laboratory. Human milk was shielded from light at all times. Three pooled samples of each treatment were analyzed at each analysis point. Refrigerated samples were analyzed for fatty acid and vitamin content every 48 hours for 6 days. Frozen samples $\left(-20^{\circ} \mathrm{C}\right.$ or $\left.-80^{\circ} \mathrm{C}\right)$ were analyzed at week 2 , week 3 , week 4 and then every calendar month for a total of 6 months. This study was approved by the University of Manitoba Ethics Committee, Bannatyne Campus Research Ethics Boards, and Ethics Reference Number: H2008:217.

\section{Determination of riboflavin and total vitamin C}

Riboflavin and vitamin $\mathrm{C}$ were analyzed according to Zafra-Gomez et al. [48]. Prior to the initialization of the procedure, aliquots of human milk were warmed in water $\left(40^{\circ} \mathrm{C}\right)$ until the contents reached a temperature of $38^{\circ} \mathrm{C}$, in order to liquidize milk fat and to dissolve lipids adhered to the walls of the containers [49]. Dithiothreitol (DTT) (Sigma-Aldrich) was used for the reduction of DHAA to AA $[27,32]$. Peak separation was carried out in the Agilent 1100 series HPLC (Agilent Technologies, Waldbronn, Germany). Waters Spherisorb ODS2, $\mathrm{C}_{18}$ $250 \times 4.6 \mathrm{~mm}$ I.D. A $5 \mu \mathrm{m}$ analytical column was used, protected with a Waters Spherisorb ODS2, $C_{18}, 10 \times 4.6 \mathrm{~mm}$ I.D. $5 \mu \mathrm{m}$ guard cartridge. Gradient elution was: initial values $98 \% \mathrm{~A}$ and $2 \% \mathrm{~B}$; then a decrease of A to $10 \%$ over $8 \mathrm{~min}$; hold for $10 \mathrm{~min}$; an increase of A to $98 \%$ and a hold for $6 \mathrm{~min}$. A constant flow rate was set at $1.0 \mathrm{ml} / \mathrm{min}$. The UV detector was set at $245 \mathrm{~nm}$ for ascorbic acid; the fluorescence detector was set at 400/520 nm (excitation/emission) for riboflavin. Peak areas were calculated by the Agilent ChemStation for LC 3D Rev. B.01.03 [204] system. Values are expressed in $\mathrm{mg} / \mathrm{L}$ (vitamin C) and ug/L (riboflavin). In order to determine vitamin retention times, a standard curve was generated immediately before each analysis of human milk samples using solutions with known concentrations of vitamin C (3.125 $\mu \mathrm{g} / \mathrm{ml}-200 \mu \mathrm{g} / \mathrm{ml})$, riboflavin $(0.078 \mu \mathrm{g} / \mathrm{ml}-5 \mu \mathrm{g} / \mathrm{ml})$ and DTT $(1.5 \mathrm{mg} /$ $\mathrm{ml})$ in $2.4 \%$ acetic acid. A linear relationship was observed between concentration and signal at these ranges. The method was validated by calculating concentrations of vitamins $\mathrm{C}$ and riboflavin at every analysis point in freshly prepared Standard Reference Material (SRM) 1849 - Infant/Adult Nutritional Formula powder (National Institute of Standards \& Technology, Gaithersburd, MD), diluted 15-fold with double distilled water $\left(\mathrm{ddH}_{2} \mathrm{O}\right)$. Results obtained at 3 months were not included in the analysis due to analytical uncertainty.

\section{Determination of LA, ALA, DHA and ARA}

Fatty acids were analyzed by gas chromatograph (Varian 450 GC, Agilent Technologies) with split injection and a flame ionization detector (GC-FID). The one-step transesterification method of Masood et al. [50] was used for preparation of fatty acid methyl esters (FAMEs). The method was validated at every analysis point using SRM 1849, diluted 15-fold with $\mathrm{ddH}_{2} \mathrm{O}$. Heptadecanoic acid (C17:0) (Nu-Chek 
Prep. Inc., USA) was used as the internal standard [51]. An Agilent J\&W DB-225MS column was used for FAMEs separation $(30 \mathrm{~m}$, $250 \mu \mathrm{m}$ I.D., and film thickness $0.25 \mu \mathrm{m}$ ). Hydrogen was the carrier gas at a flow rate of $1.3 \mathrm{ml} / \mathrm{min}$ with nitrogen as a make-up flow at $25 \mathrm{ml} / \mathrm{min}$. Hydrogen $(30 \mathrm{ml} / \mathrm{min})$ and $\operatorname{air}(300 \mathrm{ml} / \mathrm{min})$ were used for combustion. The initial temperature of the $1 \mu \mathrm{L}$ injection $(10: 1$ split ratio) was $270^{\circ} \mathrm{C}$. The column oven initial temperature was $70^{\circ} \mathrm{C}$ for $2 \mathrm{~min}$, increased to $180^{\circ} \mathrm{C}$ at $30^{\circ} \mathrm{C} / \mathrm{min}$ and held for $1 \mathrm{~min}$, increased to $200^{\circ} \mathrm{C}$ at $10^{\circ} \mathrm{C} / \mathrm{min}$ and held for $2 \mathrm{~min}$, increased to $220^{\circ} \mathrm{C}$ at $2^{\circ} \mathrm{C} /$ min and held for $4 \mathrm{~min}$ and finally increased to $240^{\circ} \mathrm{C}$ at $20^{\circ} \mathrm{C} / \mathrm{min}$ and held for $5 \mathrm{~min}$. The detector temperature was $290^{\circ} \mathrm{C}$. FAME peaks were identified by comparison with GLC Reference Standard 461 (Nu-Chek Prep, Inc. USA). Peak areas were determined by Galaxie Software and expressed as "composition \%" of total fatty acids.

\section{Statistical analysis}

Statistical analysis was performed using Graph Pad Prism version 5.00 for Windows, GraphPad Software, and San Diego California USA. Statistical significance was assigned to $\mathrm{P}<0.05$. For the analysis of a compound concentration change over time, one-way ANOVA with Post-Hoc Tukey's Multiple Comparison Test was performed. Two-way Repeated Measures ANOVA with Post-Hoc Bonferroni Test was used for the comparison of concentrations by treatment at the same time points.

\section{Results and Discussion}

\section{Vitamin $\mathrm{C}$ content change in refrigerated human milk}

The vitamin C content of all treatments (control, pasteurized and unheated milk stored with nitrogen gas) remained stable from the $2^{\text {nd }}$ until the $6^{\text {th }}$ day of storage (Figure 1). No statistical difference between treatments or treatments over time was observed. After the second day, the unpasteurized milk content was no higher than that of the heated milk. It may be that a major loss of vitamin $\mathrm{C}$ in human milk occurs with pasteurization $[15,42,43]$ or occurs during the first 2 days of storage if not heat-treated, with no appreciable change thereafter. Restriction of oxygen with nitrogen flushing did not affect the vitamin C content.

\section{Riboflavin content change in refrigerated human milk}

The riboflavin content was not affected by oxygen restriction or pasteurization and did not change over the 6 days of storage in all human milk samples (Figure 2). There was no statistical difference between treatments or treatments over time. A decrease may have been expected based on a study of photo degradation of several vitamins in cow's milk as reported by Fanelli et al. [52]. However, our observed heat stability of riboflavin was in agreement with Ball, [37] who reported that riboflavin is generally stable during heat treatment if light is absent.

\section{Vitamin $\mathrm{C}$ content change in frozen human milk}

There was a rapid and consistent decrease in the vitamin $\mathrm{C}$ level for all treatments during the first month of storage (Table 1). Statistical analysis indicated that the vitamin $\mathrm{C}$ content of all treatments (control, pasteurized and unheated milk stored with nitrogen gas) decreased during the first month of storage at $-20^{\circ} \mathrm{C}$ and $-80^{\circ} \mathrm{C}$ followed by a 5-month period of stability. Notably, the vitamin $\mathrm{C}$ content of the control milk stored at $-80^{\circ} \mathrm{C}$ dropped to an undetectable level during the first month, while control milk stored at $-20^{\circ} \mathrm{C}$ retained some of the vitamin as seen by others $[27,51]$. A lower storage temperature $\left(-80^{\circ} \mathrm{C}\right)$ did not provide increased stability for vitamin $\mathrm{C}$ preservation in pasteurized milk. Therefore, it may be that a $-20^{\circ} \mathrm{C}$ temperature is

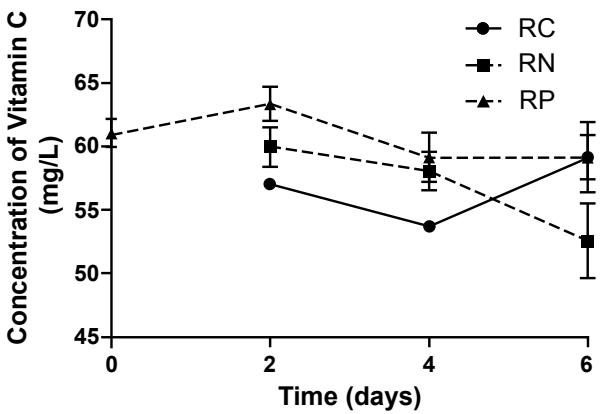

Figure 1: Vitamin $\mathrm{C}$ content of refrigerated $\left(4^{\circ} \mathrm{C}\right)$ human milk for 6 days of storage. RC - control (untreated) human milk; RN - human milk stored in nitrogen gas environment; RP - pasteurized human milk.

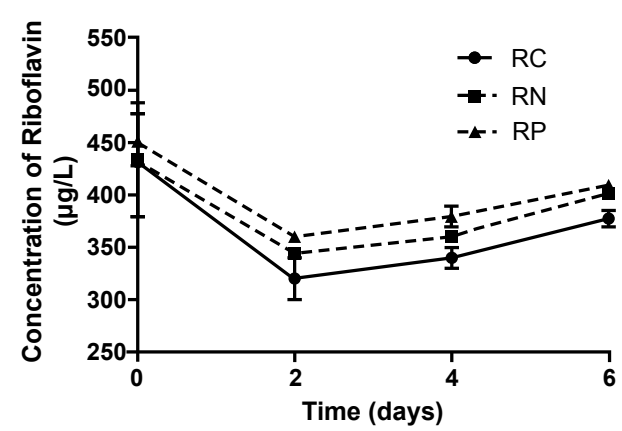

Figure 2: Riboflavin content of refrigerated $\left(4^{\circ} \mathrm{C}\right)$ human milk for 6 days of storage. RC - control (untreated) human milk; RN - human milk stored in nitrogen gas environment; RP - pasteurized human milk.

\begin{tabular}{|c|c|c|c|c|c|c|}
\hline Duration & \multicolumn{7}{|c|}{ Treatment (mg/L) } \\
\hline Month & FC & FN & FP & SC & SN & SP \\
\hline $1^{\text {st }}$ & $18.29 \pm 1.73$ & $14.23 \pm 3.11$ & $4.93 \pm 2.21$ & 0 & $14.20 \pm 2.20$ & $13.28 \pm 1.91$ \\
\hline $2^{\text {nd }}$ & $18.15 \pm 1.87$ & $10.36 \pm 1.34$ & $18.35 \pm 1.56$ & 0 & $14.15 \pm 2.22$ & $12.57 \pm 0.64$ \\
\hline $3^{\text {rd }}$ & $2.87 \pm 0.70$ & $3.88 \pm 0.79$ & $3.56 \pm 0.15$ & 0 & $3.98 \pm 0.00$ & $2.99 \pm 1.06$ \\
\hline $4^{\text {th }}$ & $16.71 \pm 0.62$ & $20.89 \pm 0.62$ & $9.40 \pm 1.89$ & $2.10 \pm 0.12$ & $4.30 \pm 1.92$ & $4.67 \pm 0.85$ \\
\hline $5^{\text {th }}$ & $13.34 \pm 0.54$ & $18.05 \pm 1.15$ & $6.54 \pm 0.94$ & $6.12 \pm 0.48$ & $7.31 \pm 0.58$ & $8.46 \pm 0.91$ \\
\hline $6^{\text {th }}$ & $20.81 \pm 1.41$ & $26.22 \pm 1.44$ & $11.16 \pm 0.83$ & $4.82 \pm 0.43$ & $5.67 \pm 0.53$ & $5.95 \pm 0.12$ \\
\hline
\end{tabular}

Table 1: Vitamin $\mathrm{C}$ content of frozen human milk $\left(-20^{\circ} \mathrm{C}\right.$ and $\left.-80^{\circ} \mathrm{C}\right)$ for 6 months of storage. $\mathrm{FC}$ - control (untreated) human milk stored at $-20^{\circ} \mathrm{C}$; FN - human milk stored at $-20^{\circ} \mathrm{C}$ in a nitrogen gas environment; FP - pasteurized human milk stored at $-20^{\circ} \mathrm{C}$; $\mathrm{SC}$ - control (untreated) human milk stored at $-80^{\circ} \mathrm{C}$; $\mathrm{SN}$ - human milk stored at $-80^{\circ} \mathrm{C}$ in a nitrogen gas environment; SP - pasteurized human milk stored at $-80^{\circ} \mathrm{C}$. The concentrations are expressed as $\mathrm{mg} / \mathrm{L}$ for vitamin $\mathrm{C}$, mean $+/-\mathrm{SE}$.

preferable over $-80^{\circ} \mathrm{C}$ for optimal storage of human milk. Flushing with nitrogen improved the preservation of vitamin $\mathrm{C}$ in unpasteurized human milk compared to controls stored at both temperatures. However, the small changes do not appear to justify the expenses involved in oxygen removal.

\section{Riboflavin content change in frozen human milk}

Control human milk samples retained their riboflavin content for 6 months of storage at both temperatures $\left(-20^{\circ} \mathrm{C}\right.$ and $\left.-80^{\circ} \mathrm{C}\right)$, as reported by others [53], with no advantage to either (Table 2). A nitrogen gas environment lowered riboflavin levels compared to controls in contrast to the expected preservation effect of oxygen restriction [18]. In the stored pasteurized samples, riboflavin levels decreased at both temperatures. At the end of the storage period of 6 months, all samples retained appreciable levels of riboflavin compared with initial concentrations. 
Citation: Abramovich M, Friel JK, Hossain Z (2013) Polyunsaturated Fatty Acids, Riboflavin and Vitamin C: Effect of Different Storage Conditions of Human Milk. Vitam Miner 2: 110.

Page 4 of 5

\section{LA, ALA, DHA and ARA content change in refrigerated human milk}

Statistical analysis of the four fatty acids in the 3 types of human milk (LA only, Figure 3) revealed only non-significant fluctuations in their concentrations from one analysis point to another and between different treatments. Overall, the 4 FAs remained stable during the 6 days of storage at $4^{\circ} \mathrm{C}$, in agreement with Slutzah et al. [54] (storage for 4 days) and Tacken et al. [41] (storage for 2 days), and were not affected by Holder pasteurization, as supported by other studies $[15,44,55,56]$. For LA, ALA, DHA and ARA, during refrigeration (at $\left.4^{\circ} \mathrm{C}\right)$ for 6 days, there was no advantage or detrimental effect of oxygen restriction.

\section{LA, ALA, DHA and ARA content change in frozen human milk}

All four fatty acids remained stable independent of treatment for 6 months of storage at $-20^{\circ} \mathrm{C}$ and at $-80^{\circ} \mathrm{C}$. Therefore, results are presented for LA (Table 3 ) only. These results were in agreement with other reports that indicate stability of human milk fat stored in similar conditions $[39,41,56]$. The observed stability of the four fatty acids with all treatments during 6 months of storage at $-20^{\circ} \mathrm{C}$ and at $-80^{\circ} \mathrm{C}$ suggests that a lower storage temperature of $-80^{\circ} \mathrm{C}$ may not be necessary for FA preservation and that oxygen restriction adds no advantage. The stability of the fatty acids is not a novel finding [54,55], although polyunsaturated fatty acids are sensitive to light, oxygen exposure and high temperature. In milk they are incorporated into fat globules that are membrane bound. As long as milk is carefully handled, the globule membranes protect fatty acids [55].

\section{Conclusions}

The study's objective was the evaluation of the shelf life of expressed human milk under a variety of storage conditions. The results of

\begin{tabular}{|c|c|c|c|c|c|c|}
\hline Duration & \multicolumn{5}{|c|}{ Treatment $(\mu \mathrm{g} / \mathrm{L})$} \\
\hline Month & FC & FN & FP & SC & SN & SP \\
\hline $1^{\text {st }}$ & $317.50 \pm 3.82$ & $282.50 \pm 0.00$ & $320.00 \pm 2.50$ & $322.50 \pm 2.89$ & - & $304.17 \pm 3.00$ \\
\hline $2^{\text {nd }}$ & $392.50 \pm 2.89$ & $355.83 \pm 2.20$ & $392.50 \pm 2.89$ & $355.83 \pm 2.20$ & $403.33 \pm 5.46$ & $404.17 \pm 1.67$ \\
\hline $3^{\text {rd }}$ & $470.83 \pm 1.67$ & $431.67 \pm 0.75$ & $470.83 \pm 1.67$ & $431.67 \pm 2.20$ & $475.00 \pm 2.50$ & $477.50 \pm 1.44$ \\
\hline $4^{\text {th }}$ & $374.17 \pm 3.63$ & $339.17 \pm 0.83$ & $374.17 \pm 3.63$ & $339.17 \pm 0.83$ & $382.50 \pm 1.44$ & $386.67 \pm 0.83$ \\
\hline $5^{\text {th }}$ & $416.67 \pm 3.63$ & $370.83 \pm 6.51$ & $416.67 \pm 3.63$ & $370.83 \pm 6.51$ & $417.50 \pm 1.44$ & $420.83 \pm 3.33$ \\
\hline $6^{\text {th }}$ & $385.00 \pm 0.00$ & $324.17 \pm 7.41$ & $389.17 \pm 2.21$ & $324.17 \pm 7.41$ & $389.17 \pm 2.20$ & $397.50 \pm 6.61$ \\
\hline
\end{tabular}

Table 2: Riboflavin content of frozen human milk $\left(-20^{\circ} \mathrm{C}\right.$ and $\left.-80^{\circ} \mathrm{C}\right)$ for 6 months of storage. $\mathrm{FC}$ - control (untreated) human milk stored at $-20^{\circ} \mathrm{C}$; FN - human milk stored at $-20^{\circ} \mathrm{C}$ in a nitrogen gas environment; FP - pasteurized human milk stored at $-20^{\circ} \mathrm{C}$; SC - control (untreated) human milk stored at $-80^{\circ} \mathrm{C}$; $\mathrm{SN}$ - human milk stored at $-80^{\circ} \mathrm{C}$ in a nitrogen gas environment; SP - pasteurized human milk stored at $-80^{\circ} \mathrm{C}$. The concentrations are expressed as $\mu \mathrm{g} / \mathrm{L}$ for riboflavin, mean $\pm \mathrm{SEM}$.

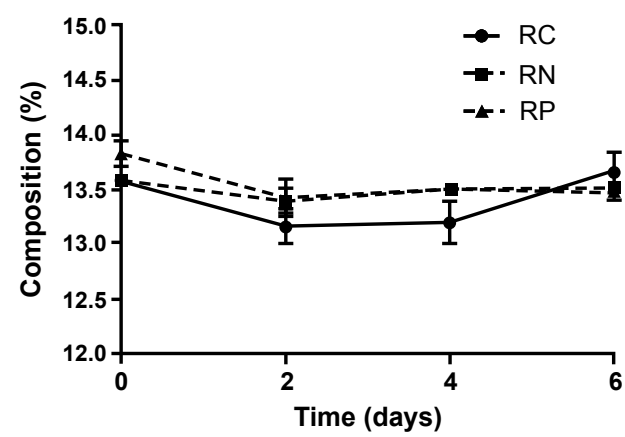

Figure 3: LA content of refrigerated human milk $\left(4^{\circ} \mathrm{C}\right)$ for 8 days of storage. $\mathrm{RC}$ - control (untreated) human milk; RN - human milk stored in nitrogen gas environment; RP - pasteurized human milk.

\begin{tabular}{|c|c|c|c|c|c|c|}
\hline Duration & \multicolumn{7}{|c|}{ Treatment (composition \%) } \\
\hline Month & FC & FN & FP & SC & SN & SP \\
\hline $1^{\text {st }}$ & $13.69 \pm 0.23$ & $13.60 \pm 0.03$ & $13.53 \pm 0.15$ & $13.48 \pm 0.04$ & $13.55 \pm 0.08$ & $13.54 \pm 0.17$ \\
\hline $2^{\text {nd }}$ & $14.70 \pm 0.04$ & $14.62 \pm 0.02$ & $14.64 \pm 0.02$ & $14.67 \pm 0.00$ & $14.61 \pm 0.02$ & $14.58 \pm 0.01$ \\
\hline $3^{\text {rd }}$ & $14.65 \pm 0.04$ & $14.86 \pm 0.03$ & $14.81 \pm 0.06$ & $14.71 \pm 0.05$ & $14.87 \pm 0.00$ & $14.80 \pm 0.07$ \\
\hline $4^{\text {th }}$ & $15.47 \pm 0.02$ & $15.39 \pm 0.07$ & $15.30 \pm 0.09$ & $15.44 \pm 0.03$ & $15.46 \pm 0.10$ & $15.28 \pm 0.02$ \\
\hline $5^{\text {th }}$ & $15.47 \pm 0.05$ & $15.31 \pm 0.09$ & $15.29 \pm 0.07$ & $15.36 \pm 0.11$ & $15.41 \pm 0.02$ & $15.34 \pm 0.01$ \\
\hline $6^{\text {th }}$ & $15.56 \pm 0.10$ & $15.45 \pm 0.09$ & $15.47 \pm 0.03$ & $15.46 \pm 0.07$ & $15.38 \pm 0.07$ & $15.56 \pm 0.06$ \\
\hline
\end{tabular}

Table 3: LA acids content of frozen human milk $\left(-20^{\circ} \mathrm{C}\right.$ and $\left.-80^{\circ} \mathrm{C}\right)$ for 6 months of storage. Results for the analysis of LA concentration in human milk stored in the freezer at $-20^{\circ} \mathrm{C}$ and at $-80^{\circ} \mathrm{C}$ for 6 months not treated ( $\mathrm{FC}$ for $-20^{\circ} \mathrm{C}$; SC for $-80^{\circ} \mathrm{C}$ ), in nitrogen gas environment ( $\mathrm{FN}$ for $-20^{\circ} \mathrm{C}$; $\mathrm{SN}$ for $-80^{\circ} \mathrm{C}$ ) or pasteurized prior to storage ( $\mathrm{FP}$ for $-20^{\circ} \mathrm{C}$; SP for $-80^{\circ} \mathrm{C}$ ). The concentrations are expressed as "composition (\%)" for LA, mean \pm SEM.

this study showed that out of the 6 nutrients analyzed, the limiting nutrient for stored human milk is vitamin C. The 4 fatty acids and the vitamin riboflavin maintained general stability under all experimental conditions. These results were in a general agreement with previous reports. The results of this study for vitamin C, riboflavin, LA, ALA, ARA and DHA support most storage recommendations [2,16,20-25], which are based on avoiding bacterial growth [27]. Our results also showed that raw human milk storage can be extended with Holder pasteurization. This study also showed that the exclusion of oxygen and a freezing temperature of $-80^{\circ} \mathrm{C}$, which are widely acceptable means of shelf life extension of stored food products $[15,18]$ and other human tissues provide no advantage for human milk storage over at least 6 months. Thus additional means and expensive equipment for the optimal preservation of expressed human milk in the hospital or at home are not required. For growth and development, infants need an optimum supply of ascorbic acid $[35,36]$. We recommend adding vitamin $\mathrm{C}$ to human milk at the adequate index level before feeding, if milk had been frozen for longer than 2 weeks, as previously suggested by Romeu-Nadal et al. [40].

\section{Acknowledgements}

Haifeng Yang, Leah Gillingham and Dennis Labossiere are kindly acknowledged for their assistance with the execution of this study. The voluntee mothers are gratefully acknowledged for donating samples of their breast milk. Manitoba Institute of Child Health, AFM Canada and the Faculty of Graduate Studies of the University of Manitoba provided financial support for this study.

\section{References}

1. (1997) Breastfeeding and the use of human milk. American Academy of Pediatrics. Work Group on Breastfeeding. Pediatrics 100: 1035-1039.

2. Gartner LM, Morton J, Lawrence RA, Naylor AJ, O'Hare D, et al. (2005) Breastfeeding and the use of human milk. Pediatrics 115: 496-506.

3. World Health Organization (2002) The World Health Organization's infant feeding recommendation.

4. Arnold LD (1990) Clinical uses of donor milk. J Hum Lact 6: 132-133.

5. Auerbach KG, Avery JL (1981) Induced lactation. A study of adoptive nursing by 240 women. Am J Dis Child 135: 340-343.

6. Biervliet FP, Maguiness SD, Hay DM, Killick SR, Atkin SL (2001) Induction of lactation in the intended mother of a surrogate pregnancy: case report. Hum Reprod 16: 581-583.

7. Buchko BL, Pugh LC, Bishop BA, Cochran JF, Smith LR, et al. (1994) Comfort measures in breastfeeding, primiparous women. J Obstet Gynecol Neonatal Nurs 23: 46-52.

8. Chapman DJ, Young S, Ferris AM, Perez-Escamilla R (2001) Impact of breas pumping on lactogenesis stage II after cesarean delivery: a randomized clinical trial. Pediatrics 107: E94.

9. Hills-Bonczyk SG, Avery MD, Savik K, Potter S, Duckett LJ (1993) Women's experiences with combining breast-feeding and employment. J Nurse Midwifery 38: 257-266.

10. Meserve $Y$ (1982) Management of postpartum breast engorgement in 
Citation: Abramovich M, Friel JK, Hossain Z (2013) Polyunsaturated Fatty Acids, Riboflavin and Vitamin C: Effect of Different Storage Conditions of Human Milk. Vitam Miner 2: 110.

nonbreastfeeding women by mechanical extraction of milk. J Nurse Midwifery 27: 3-8.

11. Diehl-Jones WL, Askin DF (2004) Nutritional modulation of neonatal outcomes. AACN Clin Issues 15: 83-96.

12. Human Milk Banking Association of North America (2010).

13. Israel-Ballard KA, Chantry CJ, Dewey KG, Donovan RM, Sheppard HW, et al. (2006) Heat treating breast milk as an infant feeding option. J Hum Lact 22: 267-268.

14. Baker RD, Greer FR; Committee on Nutrition American Academy of Pediatrics (2010) Diagnosis and prevention of iron deficiency and iron-deficiency anemia in infants and young children (0-3 years of age). Pediatrics 126: 1040-1050.

15. Jensen RG (1995) Miscellaneous Factors Affecting Composition and Volume of Human and Bovine Milks. In: Handbook of Milk Composition. Academic Press, San Diego, California.

16. Arslanoglu S, Bertino E, Tonetto P, De Nisi G, et al. (2010) Guidelines for the establishment and operation of a donor human milk bank J Matern Fetal Neonatal Med 2: 1-20.

17. Olson RL (1968) Objective Tests for Frozen Food Quality. In: Low Temperature Biology of Foodstuffs. Pergamon Press Ltd,Oxford.

18. Singh TK, Cadwallader KR (2000) Ways of Measuring Shelf-Life and Spoilage. In: Understanding and Measuring the Shelf-Life of Food. Edited by Steele R, Woodhead Publishing Limited, England

19. Friel JK, Diehl-Jones B, Cockell KA, Chiu A, Rabanni R, et al. (2011) Evidence of oxidative stress in relation to feeding type during early life in premature infants. Pediatr Res 69: 160-164.

20. Government of Western Australia, Department of Health (2006) NCCU Clinical Guidelines Section 7: Breast feeding: Handling, transport and storage of expressed breast milk. Perth, Western Australia: King Edward Memorial/ Princess Margaret Hospitals.

21. La Leche League International (2009) What are the LLLI guidelines for storing my pumped milk?

22. (2010) Breastfeeding... Your baby's first food. Winnipeg Public HealthGovernment of Manitoba.

23. (2004) Academy of Breastfeeding Medicine, Clinical Protocol Number \#8: Human Milk Storage Information for Home Use for Healthy Full Term Infants.

24. Lucile Packard Foundation for Children's Health (2008) Practical considerations when storing your breast milk.

25. Government of British Columbia. Baby's Best Chance (2005) Parents Handbook of Pregnancy and Baby Care.

26. Hamosh M, Ellis LA, Pollock DR, Henderson TR, Hamosh P (1996) Breastfeeding and the working mother: effect of time and temperature of shortterm storage on proteolysis, lipolysis, and bacterial growth in milk. Pediatrics 97: 492-498.

27. Buss IH, McGill F, Darlow BA, Winterbourn CC (2001) Vitamin C is reduced in human milk after storage. Acta Paediatr 90: 813-815.

28. Valentine CJ, Wagner CL (2013) Nutritional management of the breastfeeding dyad. Pediatr Clin North Am 60: 261-274.

29. Friedman Z, Danon A, Stahlman MT, Oates JA (1976) Rapid onset of essentia fatty acid deficiency in the newborn. Pediatrics 58: 640-649.

30. Heird WC, Lapillonne A (2005) The role of essential fatty acids in development Annu Rev Nutr 25: 549-571.

31. Martinez M (1992) Tissue levels of polyunsaturated fatty acids during early human development. J Pediatr 120: S129-138.

32. Fleith M, Clandinin MT (2005) Dietary PUFA for preterm and term infants: review of clinical studies. Crit Rev Food Sci Nutr 45: 205-229.

33. Jensen CL, Voigt RG, Llorente AM, Peters SU, Prager TC, et al. (2010) Effects of early maternal docosahexaenoic acid intake on neuropsychological status and visual acuity at five years of age of breast-fed term infants. J Pediatr 157 : 900-905.

34. Jensen CL, Voigt RG, Prager TC, Zou YL, Fraley JK, et al. (2005) Effects of maternal docosahexaenoic acid intake on visual function and neurodevelopment in breastfed term infants. Am J Clin Nutr 82: 125-132.

35. Francis J, Rogers K, Brewer P, Dickton D, Pardini R (2008) Comparative analysis of ascorbic acid in human milk and infant formula using varied milk delivery systems. Int Breastfeed J 3: 19

36. Romeu-Nadal M, Morera-Pons S, Castellote AI, LÃ $\tilde{A}^{3}$ ez-Sabater MC (2006) Rapid high-performance liquid chromatographic method for Vitamin C determination in human milk versus an enzymatic method. J Chromatogr B Analyt Technol Biomed Life Sci 830: 41-46.

37. Ball GFM (2006) Vitamins in Foods: Analysis, Bioavailability, and Stability CRC Press, Florida.

38. McCormick DB (1994) Riboflavin. In: Modern Nutrition in Health and Disease Edited by Shils ME, Olson JA, Shike M, Lea and Febiger, Philadelphia.

39. Berkow SE, Freed LM, Hamosh M, Bitman J, Wood DL, et al. (1984) Lipases and lipids in human milk: effect of freeze-thawing and storage. Pediatr Res 18 1257-1262.

40. Romeu-Nadal M, Castellote Al, Lopez-Sabater MC (2008) Effect of cold storage on vitamins $C$ and $E$ and fatty acids in human milk. Food Chem 106: 65-70.

41. Tacken KJ, Vogelsang A, van Lingen RA, Slootstra J, Dikkeschei BD, et al. (2009) Loss of triglycerides and carotenoids in human milk after processing Arch Dis Child Fetal Neonatal Ed 94: F447-450.

42. Van Zoeren-Grobben D, Schrijver J, Van den Berg H, Berger HM (1987) Human milk vitamin content after pasteurisation, storage, or tube feeding. Arch Dis Child 62: 161-165.

43. Romeu-Nadal M, Castellote Al, Gaya A, et al. (2008) Effect of pasteurisation on ascorbic acid, dehydroascorbic acid, tocopherols and fatty acids in pooled mature human milk. Food Chem 107: 434-438.

44. Henderson TR, Fay TN, Hamosh M (1998) Effect of pasteurization on long chain polyunsaturated fatty acid levels and enzyme activities of human milk. J Pediatr 132: 876-878.

45. Arnold LD (1995) Storage containers for human milk: an issue revisited. J Hum Lact 11: 325-328.

46. de Oliveira PR, Yamamoto AY, de Souza CB, de Ara Ãojo NM, de Andrade Gomes S, et al. (2009) Hepatitis B viral markers in banked human milk before and after Holder pasteurization. J Clin Virol 45: 281-284.

47. Tully MR (2001) Excel $\tilde{A}^{a}$ ncia em bancos de leite humano: uma visÃ£o do futuro--the First International Congress on Human Milk Banking. J Hum Lact 17: $51-53$.

48. Zafra-GÃ $\tilde{A}^{3} \mathrm{z}$ A, Garballo A, Morales JC, GarcÃa-Ayuso LE (2006) Simultaneous determination of eight water-soluble vitamins in supplemented foods by liquid chromatography. J Agric Food Chem 54: 4531-4536.

49. Jensen RG, Clark RM (1984) Methods of lipid analysis. J Pediatr Gastroentero Nutr 3: 296-299.

50. Masood A, Stark KD, Salem N Jr (2005) A simplified and efficient method for the analysis of fatty acid methyl esters suitable for large clinical studies. J Lipid Res 46: 2299-2305.

51. Ezz El Din ZM, Abd El Ghaffar S, El Gabry EK, Fahmi WA, Bedair RF (2004) Is stored expressed breast milk an alternative for working Egyptian mothers? East Mediterr Health J 10: 815-821.

52. Fanelli AJ, Burlew JV, Gabriel MK (1985) Protection of milk packaged in high density polyethylene against photodegradation by fluorescent light. J Food Pro 48: 112

53. Engler PP, Bowers JA (1976) B-vitamin retention in meat during storage and preparation. A review. J Am Diet Assoc 69: 253-257.

54. Slutzah M, Codipilly CN, Potak D, Clark RM, Schanler RJ (2010) Refrigerator storage of expressed human milk in the neonatal intensive care unit. J Pediatr 156: $26-28$.

55. Fidler N, Sauerwald TU, Koletzko B, Demmelmair H (1998) Effects of human milk pasteurization and sterilization on available fat content and fatty acid composition. J Pediatr Gastroenterol Nutr 27: 317-322.

56. Friend BA, Shahani KM, Long CA, et al. (1983) Evaluation of freeze drying, pasteurization, high-temperature heating and storage on selected enzymes, $\mathrm{B}$ vitamins and lipids of human milk. J Food Prot 46: 330-334. 